\title{
Teacher and Students' Perception on Content and Language Integrated Learning (CLIL) Based Kalam III Material Model Design
}

\author{
Mohamad Sarip, Zainal Rafli, Aceng Rahmat \\ \{Mohamad_Sarip@unj.ac.id ${ }^{1}$, zainal.rafli@gmail.com ${ }^{2}$, Aceng57@gmail.com ${ }^{3}$ \} \\ Arabic Program of Language and Art Faculty, Jakarta State Univerity Indonesia ${ }^{1,2,3}$
}

\begin{abstract}
The aim of this study is to know teacher and students' perception on Kalam III material that have been designed using Content and Language Integrated Learning at Jakarta State University. It is because of the students' ability in Kalam III is still low. This research used descriptive qualitative method. The data ware took by observation, questionnaire and interview. The research finding shows that Kalam III material based CLIL using Qur'an, Hadits, Fiqih and Tsaqofah Islamiah is an effective model for improving students' Arabic ability. It can be seen from the perception of students and teachers.
\end{abstract}

Keywords: Arabic, Kalam, CLIL, Perception, Teaching Material,

\section{Introduction}

Arabic for Indonesian Muslims is a language that has been embedded in their daily lives, especially in the five daily prayers and reading the Holy Qur'an, including the many vocabulary in Indonesian. Arabic, Al-Qur'an and hadith are like two sides of a coin that cannot be separated from one another. This condition certainly provides opportunities for formal and informal educational institutions that teach Arabic material. In fact, the number of formal and informal education institutions that teach Arabic language material has significantly increased. The increasing number of educational institutions should be followed by the need for quality learning. So that every graduate from formal and informal education institutions can communicate using Arabic in accordance with Arabic fusha (standard).

Thus, in order to support the process of Arabic communicating as well, the ability of Arabic speaking is fluent. Speaking skills are one of the language skills that are considered difficult to master. This is because speaking has not been used as a language of daily communication and the influence of other factors on the teaching and learning process so far at Jakarta State University. In the Arabic Language Education Study Program, Jakarta State University found that the ability to speak Arabic became one of the types of language skills that would be achieved in the teaching of modern foreign languages. This is because talking is a medium for building reciprocal communication. The media builds mutual understanding through language. As with language learning, the process of achieving the ability to communicate the language and respond to what is heard so that reciprocal communication occurs between the speaker and listener to create professional conditions. The concept is one 
of the learning achievement targets to be achieved from the implementation of the Arabic Language Education Program at Jakarta State University that graduates have the ability to speak Arabic that meets international standards. It is in Kalam III subject.

Therefore, education process needs the material that is appropriate students' needs and global. Material has fundamental position in learning and teaching process. Based on the results of observations, interviews and questionnaires that have been distributed to students can be identified about the constraints and obstacles faced by students in mastering and studying subjects in Kalam III. Difficulties faced by students who study Kalam III courses come from three factors; 1) student factors relate with the linguistic and non-linguistic aspects., 2) teaching material is available but it has not supported students' speaking competence. This is because students tend to put more emphasis on memorizing dialogue and discourse texts, and learning methodology used. 3) the last factor is from the teacher that has focused to the audio-lingual method. It can be concluded that Arabic speaking learning needs appropriate material using the appropriate method learning. To realize it, research is needed that is not only oriented to produce teaching materials, but designing the needs of teaching materials in accordance with the needs of learning methods. One of the learning methods offered is Content and Language Integrated Learning (CLIL). According to Coyle, "Language is a conduit for communication and for learning which can be described as learning to use language and using language to learn." [1] Therefore, the Arabic speaking learning needs appropriate approach.

A large volume of research studies has done and it gives the effectiveness of Arabic learning, like as Yakub [2] found the integrated approach in speaking Arabic skills. This approach has the same way with the CLIL. The difference that is implementing of objective, as Arifin and Ismail has done. [3]Furthermore, Dourda combines Games Based Learning (GBL) and CLIL that post test results show significantly different results for vocabulary acquisition and reading skills in foreign language. [4] From these result, it can know that speaking is complex process.

Speaking skills (maharah al-kalam) is the ability to express articulation sounds or words to express thoughts in the form of ideas, opinions, desires, or feelings to the speaking partner. In a broader sense, speaking is a system of signs that can be heard and seen that utilizes a number of muscles in the human body to convey thoughts in order to meet their needs. [5] Abdurrahman, explaining the purpose of speaking skills in learning Arabic, students can: (a) Develop the ability to speak skills for students properly and correctly, (b) Grow the wealth of language that students have, (c) Functioning their language knowledge in terms of mufradat and composition of sentences correctly and trigger them to go forward and be able to reproduce it, (d) Grow the ability of students in making / creating in situations and conditions expressed in Arabic, (e) Triggering students to always practice Arabic, (f) Understanding every communication and being trained to communicate, $(\mathrm{g})$ Motivated to communicate in front of his friends and not afraid of wrong pronunciation. [6]

Thus, in order for the learning process of Arabic language skills run well, a lecturer must give attention to several important principles as explained by Rosyidi and Ni'mah as follows:[7]

1. Teachers should have high skills about these skills.

2. Starting with similar voices between two languages (student language and Arabic)

3. The author and instructor should give attention to the stages in teaching kalam, such as starting with easy lafadz consisting of one sentence, two sentences, and so on.

4. Start with an easy vocabulary

5. Focusing on the skills for speaking skills, namely: 
a. The way to pronounce the sound from its master properly and correctly

b. Distinguish the pronouncement of long and short.

c. Express ideas in the right way by taking into account the existing grammar rules

d. Train students how to start and end talk correctly.

e. Increase exercises, such as training to distinguish sound pronunciation, practice expressing ideas, and so on

Thus, researchers chose the CLIL approach as the main basis for applying Kalam III materials. This is due to several reasons; first because CLIL is a learning approach that combines language and content approaches, where a second language or a foreign language is not only used as a language in learning instruction but also as a very important tool for building knowledge. Initially, the term CLIL was used in the context of European countries to refer to the success of learning efforts through the use of additional languages in various types of schools. The use of additional languages which is the national language of neighboring countries and the language of the majority in the country itself. One of the research efforts that has been carried out in Finland by applying the CLIL concept, which mostly focuses on students and learning outcomes. The effect of CLIL is the target of language learning, language specific skills, and the development of mother tongue. [8]

Content and Language Integrated Learning (CLIL) is a learning approach centered on content as well as an introductory language used in learning. Marsh et al. states that: "CLIL is a dual-focused educational approach in which an additional language is used for learning and teaching and learning with predisposed levels".[9]So, CLIL is very appropriate to be used as a learning approach in bilingual schools, which uses foreign languages as the language of instruction in learning. CLIL is also related to content-based teaching based on a dual focus on the language and content taught. [10]In addition to Content-Based Instruction (CBI), CLIL is also often associated with types of English learning with special objectives or ESP. This association has to do with the characteristics of ESP where learning a foreign language is also carried out by giving great attention to the subject content that is pursued by the learners. As stated by Coyle, Hood, and Marsh the content in the CLIL setting can also be thematic, crosscurricular, interdisciplinary or have a focus on citizenship. [11] Thus, CLIL will be success in process of learning when it has appropriate the material.

In the learning process, teaching material has an important role in the learning process in order to achieve the desired results, both understanding and competency skills that will be used or processed to achieve results. These results are in the form of understanding and ability of students. The importance of teaching material in learning activities can be a component that must exist in the learning process. Materials 'include anything which can be used to facilitate the learning of a language. They can be linguistic, visual, auditory or kinaesthetic, and they can be presented in print, through live performance or display, or on cassette, CD-ROM, DVD or the internet.[12]

Dudley-Evans and St. John observed that "only a small proportion of good teachers of course materials."[13] From this opinion it was concluded that teaching material is a medium used to influence the process of teaching and learning language. A good teacher has a creative way of developing learning teaching materials. In Arabic, material is called Al-Mawad alDirasiyah or some call it Al-Mawad al-Ta'limiyah is important in a teaching and learning process, and is a factor that influences quality of education. With the existence of Al-Mawad al-Dirasiyah, the role of teachers and students in the teaching and learning process is changing. Teachers are no longer the main and only source in obtaining information about learning materials, as well as students, they can be free and loose in obtaining information 
about learning material, because learning materials can be obtained from sharing sources where students are, such as from the mass media, textbooks, cassettes, CDs, VCDs and so on. These sources of information can be used as Al-Mawad al-Dirasiyah. [14]

Tomlinson also describes a principle and flexible framework designed to help teachers develop material efficiently and effectively and Penaflorida reports on the use of six material design principles identified by Nunan:

1. Material must be clearly related to the curriculum used

2. Material must be authentic in the text and assignment

3. Material must encourage the interaction process.

4. Material must encourage students to focus on formal aspects of language

5. Material must encourage students to develop their learning abilities

6. Material must encourage students to use the development of abilities that have been widely studied outside the classroom. [15]

Therefore, the Kalam III material that has been designed requires the assessment of students and lecturers to find out whether it is in accordance with the needs of students and globally. Students and lecturers' perceptions have an important role in the level of effectiveness of teaching material models. This is because students as principals of the learning process in class who will receive the teaching material that has been designed. while lecturers as designers who design the achievement of goals and competencies that must be owned by students. Based on that explanation, the formulation of problem in this study is "how are the teacher and students' perception on Kalam III material design using CLIL?"

\section{Method}

\subsection{Methods}

The method of the study is research and development using descriptive qualitative method. It is to study intensely a phenomenon to discover patterns and themes about life events when the research has specific questions about the phenomenon. There are two qualitative descriptive approaches, the exploratory study and the case study.[16] The research is an investigation of teacher and students' perception on Kalam III material designing.

\subsection{Participant of Research}

The participants of research are teacher and students. The location of research is Arabic Education at Jakarta State University.

\subsection{The process of Collecting Data}

The process of collecting data for this research are;

1. Observation.

Observations in the form of field notes were conducted to find out more deeply the perceptions of students and teachers on the teaching material that had been tested in class.

2. Interviews

Interviews aim to obtain views about the learning approaches, methods and strategies of students in the learning process. 
3. Questionnaire.

The questionnaire is closed which contains questions and answer choices that have been provided and chosen by the respondent.

\subsection{The Technique of Data Analysis}

In conducting data analysis, researchers used qualitative approaches. Qualitative data in the form of descriptive, in the form of verbal or written words given by teachers and students. Thus, the qualitative approach is used to obtain information on the effectiveness of teaching materials. Data analysis also uses expert judgment.

\section{Finding And Discussion}

Kalam III material is designed to full students' needs in Arabic learning. The material has made will be conducted a feasibility trial by taking perception from 2 teachers and 25 students. This is done to improve the results of the development of teaching material models that are in line with the needs of students. The following is the result of teacher's perception on Kalam III material using CLIL;

Table 1. The Result of Judgment Expert

\begin{tabular}{|c|c|c|c|c|c|}
\hline \multirow{2}{*}{ Part } & \multirow{2}{*}{ Components } & \multicolumn{2}{|c|}{ Expert } & \multirow{2}{*}{ Acount } & \multirow{2}{*}{ Average } \\
\hline & & A & B & & \\
\hline \multirow[t]{7}{*}{ A } & \multicolumn{5}{|c|}{ Feasibility of Teaching Materials } \\
\hline & \multicolumn{5}{|c|}{ 1. Compliance with } \\
\hline & $\begin{array}{l}\text { core competencies } \\
\text { and indicators } \\
\text { developed }\end{array}$ & 3 & 4 & 7 & 3.5 \\
\hline & $\begin{array}{l}\text { 2. Compliance with } \\
\text { student needs }\end{array}$ & 4 & 3 & 7 & 2.5 \\
\hline & $\begin{array}{l}\text { 3. Compliance with } \\
\text { teaching materials }\end{array}$ & 3 & 4 & 7 & 3.5 \\
\hline & $\begin{array}{l}\text { 4. Actual and } \\
\text { Meaningful }\end{array}$ & 3 & 3 & 6 & 3 \\
\hline & $\begin{array}{l}\text { 5. Compliance with } \\
\text { morality / character } \\
\text { values }\end{array}$ & 4 & 4 & 8 & 4 \\
\hline \multirow[t]{8}{*}{ B } & \multicolumn{5}{|l|}{ Linguistic } \\
\hline & Readability & 4 & 3 & 7 & 3.5 \\
\hline & \multirow{2}{*}{$\begin{array}{l}\text { Information clarity } \\
\text { compatibility with } \\
\text { grammar }\end{array}$} & 3 & 4 & 7 & 3.5 \\
\hline & & 4 & 4 & 8 & 4 \\
\hline & $\begin{array}{l}\text { The use of language is } \\
\text { effective and efficient } \\
\text { Presentation }\end{array}$ & 3 & 4 & 7 & 3.5 \\
\hline & Clarity of purpose & 4 & 3 & 7 & 3.5 \\
\hline & Presentation order & 4 & 3 & 7 & 3.5 \\
\hline & Motivation & 4 & 3 & 7 & 3.5 \\
\hline
\end{tabular}




\begin{tabular}{|c|c|c|c|c|c|}
\hline & Complete information & 3 & 4 & 7 & 3.5 \\
\hline \multirow[t]{5}{*}{$\mathrm{C}$} & Design & & & & \\
\hline & Use of fonts & 3 & 4 & 7 & 3.5 \\
\hline & lay out & 3 & 4 & 7 & 3.5 \\
\hline & $\begin{array}{l}\text { Illustration, picture, } \\
\text { photo and video }\end{array}$ & 3 & 3 & 6 & 3 \\
\hline & Display design & 3 & 3 & 6 & 3 \\
\hline \multicolumn{2}{|c|}{ Account } & 77 & 78 & & 77.5 \\
\hline \multicolumn{2}{|c|}{ Average } & 3.85 & 3.39 & & 3.87 \\
\hline
\end{tabular}

Based on the table above, it can be stated that the cumulative assessment of teacher team was 84.24 on a scale of 100 and 3.37 on a scale of 4 with a good category. Thus, theoretically and conceptually based on the assessment of experts, the model of learning materials based on CLIL learning materials can be used as teaching materials for improving the Arabic speaking ability in the third semester students of Arabic Education Jakarta State University. The results of the assessment and input are useful to improve the model of teaching materials that have been made. These improvements include: there are still errors in writing sentences and punctuation marks, instructions or commands at each step of the learning must be clear and easy to understand, it is necessary to rearrange the layout of the subject, write down the website address of each picture and video downloaded so that students can access the media directly. The feasibility assessment of the model was not only given by teachers but the students gave suggestions on the development of Kalam III teaching materials that had been made after receiving the learning treatment. Here is the graph of the students' perception on Kalam III material using CLIL;

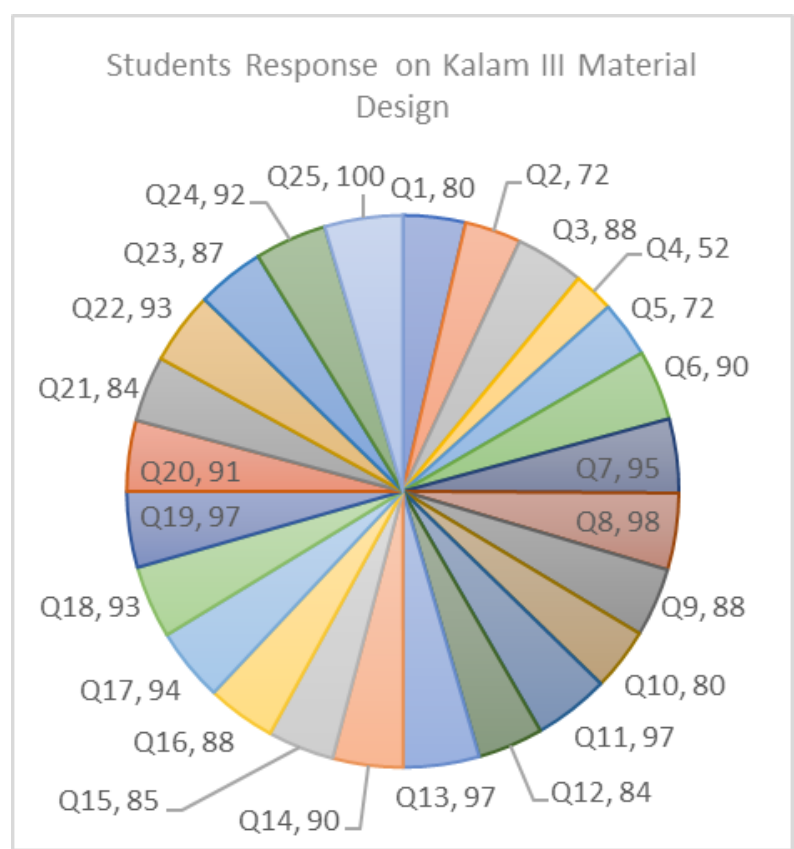

Fig.1. The Percentage of Students' Response on Kalam III Material Design 
The graph above concluded that students gave a good responses on material. There are six principles assessed and elaborated in 23 statement items. The first principle is that "Teaching materials are related to the syllabus being developed." This principle is stated in the following statement: first "The teaching material is related to the syllabus developed." The student response to this statement is $80 \%$ of students answered strongly agree, $20 \%$ of students answered agreed. The second statement is "teaching material Kalam through the CLIL approach given in accordance with my level of ability," the response given by students to this statement is $72 \%$ of students answered strongly agree, $28 \%$ of students answered agreed. The third statement is "teaching materials for Kalam through the CLIL approach given in accordance with the purpose of learning speaking skills," the response given by students to this statement is $88 \%$ of students answered strongly agree, $12 \%$ of students answered agreed. The fourth statement is "teaching material Kalam through the CLIL approach given in accordance with my level of ability" the response given by students to this statement is $52 \%$ of students answered strongly agree, $48 \%$ of students answered agreed. The fifth statement was "The teaching material of Kalam through the CLIL approach given in accordance with my level of ability" the response given by students to this statement was $72 \%$ of students answered strongly agree, $28 \%$ of students answered agreed. The sixth statement was "the teaching material of Kalam through the CLIL approach given in accordance with my level of ability" the response given by students to this statement was $90 \%$ of students answered strongly agree, $10 \%$ of students answered agreed.

The second principle is "Teaching materials encourage students to be active and interactive". This principle is stated in the following statement: first "After using teaching material based on this CLIL approach makes me dare to express ideas and ideas," the response of students to this statement is $95 \%$ of students answered totally agree, 5\% of students answered agree. The second statement was "After using teaching materials based on the CLIL approach my ability to speak Arabic increased" the response given by students to this statement was $98 \%$ of students answered strongly agree, $2 \%$ of students answered agreed. The third statement was "After using teaching material based on the CLIL approach, it was able to reconstruct the subject matter of teaching material" the response given by students to this statement was $78 \%$ of students answered strongly agree, $22 \%$ of students answered agreed. The fourth statement is "This model allows students to freely ask questions and argue" the response given by students to this statement is $80 \%$ of students answered strongly agree, $20 \%$ of students answered agreed. The fifth statement is "This model allows students to discover for themselves something new" the response given by students to this statement is $97 \%$ of students answered strongly agree, $3 \%$ of students answered agreed.

Third Principle Teaching materials are in accordance with the objectives of the developed teaching material. This principle is elaborated in 8 statements, namely, first "After using teaching material based on the CLIL approach, adding information on new knowledge and understanding aspects of Arabic used". The student response to this statement is, $16 \%$ of students answered agree, $84 \%$ answered strongly agree. The second statement in this principle is "After using teaching materials based on this CLIL approach I am more motivated to speak Arabic," the response of students to this statement is $92 \%$ of students answered strongly agree, $8 \%$ answered agreed. The third statement was "Kalam's teaching material through the CLIL approach can improve my Arabic speaking skills." The response given by students to this statement is $90 \%$ of students answered strongly agree, $20 \%$ of students answered agreed. The fourth statement was "Learning activities in groups made it easier for me to learn and more motivated to be able to speak in Arabic." The response given by students to this statement was $85 \%$ of students answered strongly agree, $15 \%$ of students answered agreed. The fifth 
statement was "Learning activities with group discussions made it easier for me to learn and more motivated to be able to speak in Arabic." The response given by students to this statement was $88 \%$ of students answered strongly agree, $12 \%$ of students answered agreed. The sixth statement was "After using teaching material based on this CLIL approach my speaking ability increased" the response given by students to this statement was $94 \%$ of students answered strongly agree, $6 \%$ of students answered agreed. The seventh statement was "After using the teaching material based on CLIL approach, I dare to interact with Arabic," the response given by students to this statement was $93 \%$ of students answered strongly agree, $7 \%$ of students answered agreed. The last statement is "The teaching material model based on the CLIL approach is suitable to improve the ability to speak Arabic," the response given by students to this statement is $97 \%$ of students answered strongly agree, $3 \%$ of students answered agreed.

The fourth principle "Teaching materials integrate four language skills". This principle is elaborated in 2 statements, first, "After using teaching material based on the CLIL approach, it adds to the ability of my four language skills." The student response to this statement is $9 \%$ of students answered agree, $91 \%$ answered strongly agree. The second statement in this principle is "After using teaching material based on this CLIL approach, it adds to my ability to hear and speak Arabic" the response of students to this statement is $84 \%$ of students answered strongly agree, $16 \%$ answered agreed

The fifth principle "Teaching materials facilitate aspects of language". This principle is elaborated in two statements, namely: "After using teaching material based on CLIL approach adds to my Arabic vocabulary," the student response to this statement is, 93\% of students answered agree, $7 \%$ answered strongly agree. The second statement in this principle is "After using teaching material based on CLIL approach, it adds to my ability to hear and speak Arabic," the students' response to this statement is $87 \%$ of students answered strongly agree and $13 \%$ answered agreed. The sixth principle is "Teaching materials build student character." This principle is elaborated in 2 statements, first, "Teaching material contains moral values for character building". Student responses to this statement are, $8 \%$ of students answered agree, $92 \%$ answered strongly agree. The second statement in this principle is "After using teaching materials based on this CLIL approach can form a better personality," student response to this statement is, $100 \%$ of students answered strongly agree.

It can be concluded that learning using teaching materials developed using the CLIL approach is an innovative approach because this approach integrates language content. In other words, the CLIL approach provides new motivation for being able encourages students to develop cognitive abilities and to achieve language skills, especially Arabic speaking ability and aspects of language. The development of CLIL-based teaching materials strongly answers the needs of students as an alternative approach to improve students' ability.

Based on the presentation of the results of the next model trial researchers describe the results of the effectiveness of the model in accordance with the analysis of data that has been collected. The effectiveness test was carried out using the pretest-posttest group design. The average score of the Pre-Test group was 76.92 and the Post-test group was 85.36. Thus, there is an increase the value of 8.44 points. While the minimum pre-test score was 68.5 and the post-test increased to 76.5 , and the maximum score in the pre-test was 84.5 , while in the posttest it was 92 . The calculation results obtained $t$-count $=5.12$, this value is greater than $t$-table, with a significant level of 0.01 and $\mathrm{dk}=48$ obtained the value of $\mathrm{t}$-table $=2.68$. The results of the test indicate that the effectiveness of the developed model is tested significantly.

The development of Kalam III for third semester students has a different development every draft of teaching material. In the initial model design, it is known that the objectives to 
be achieved in Arabic speaking learning have been adjusted to the content of the material needed in accordance with the data needs analysis. The material has 4 main components in the presentation of teaching materials, namely subjects, vocabulary, grammar, and training. The four components have the characteristics of CLIL. In the application of CLIL as said by Coyle that the process of learning a foreign language (Arabic) requires a combination of content and language itself. This means that students must learn teaching materials in Arabic and teacher as facilitators must know how to teach language. CLIL appears to complement those needs for each presentation of teaching material.

In the findings of the data analysis that the teaching material becomes more efficient and effective to use because it is directly equipped with the right learning method. Of the four elements of CLIL that complement the presentation of teaching material, it creates a unique blend to show the different characteristics of research on the development of teaching materials in Arabic. Moreover, all this time the need for teaching materials speaks Arabic and the difficulty of Arabic learning is only developed in one of the needs, for example the need to develop speaking skills for Arabic students. Like the research conducted by Yaqub.[2] This study aims to improve speaking skills for Arabic students using an integrated approach between processes and products. The results of study show that the product and process approaches have an influence on speaking skills. An integrated approach to learning to speak Arabic provides a simple example of Arabic learning materials specifically speaking skills. The results of this study provide a description of how to efficiently design teaching materials in Arabic.

In view of Coyle et al. CLIL class must involve the learning process in using language appropriately and at the same time how to use language to learn effectively. The material provides a complete presentation of learning, including: 1) culture refers to understanding and practice as the method used in understanding language. 2) Content involves knowledge and skills. 3) Cognition is related to the thinking process that leads to abilities and actions. 4) Communication reflects the ability to use language related to content and cognition in learning. The main key to implementing CLIL focuses on the level of innovation difference. So, learning innovation using CLIL refers to the application of diversity and productivity.

Thus, the development of Kalam III materials using CLIL basis has provided solutions to the need for learning Arabic both in terms of learning resource needs and learning methods. From the results of the model trials showed an increase in students' ability to speak Arabic. The effectiveness of the use of CLIL in the development of teaching materials has a fairly good influence on the teaching and learning process in the classroom. The CLIL framework in this study focuses on the language being taught. So that students become the main focus has a big role in class. As in Kiely's research that CLIL refers to the process of diversity and productivity. [2] This certainly has a broader meaning. The students learn to speak not only in the local domain but also globally. This can be seen from the results of Dourda's research that CLIL provides benefits to the learning process. [17]Students are able to have the context of the experience of speaking internationally and developing themselves. The results of Dourda's research have harmony with Kiely's research. The results of the research both have the same findings in the research on the development of teaching materials speaking Arabic based on CLIL. Students have a more varied learning experience context. Not only the context in the surrounding environment but also wider. As it is known that teaching material is equipped with learning media, namely multimedia which is realized through video. Researchers provide video content containing global content. Because Arabic has become the language of the international community. 
The development of Arabic materials has its own uniqueness compared to previous studies that have been conducted. Ghani, et.al have done an action research study that attempted to increase students' Arabic skills through a development of a learning module on Arabic language skills outside of the classroom. [18]The result of research has the same development material with Nurlaila,et.al.[19] that the product of development in the form of the model of learning is fit to be used for the learning of mahārah al- qirā'ah for students of the Arabic Language Education Department. It was a learning model with emphasis on the importance of grammatical competence and discourse competence as basic knowledge for the teaching of mahārah al-qirā'ah. With the stages of development undergone, hopefully, the resulting model set could be used in teaching and learning and could improve students' ability in the class of mahārah al-qirā'ah.

During this time, the studies conducted were oriented towards testing teaching strategies or improving students' ability to speak Arabic. While the development research provides an alternative solution to the problem of speaking Arabic, learning resources (teaching material) and the need for targeted strategies. So, the novelty value that appears in this study is seen in every aspect emerges from the CLIL element. Learning approach that is oriented to the needs of students in an integrated manner with other skills and material content related to the Indonesian context through themes taken from the Qur'an, Hadith, Morals and Tsaqofah Islamih. So that students who are still having difficulties can understand and practice teaching materials well. From cultural elements emerged in all teaching materials so that the CLIL approach builds students' mindsets and independence.

\section{Conclusion}

Development of CLIL-based teaching material models and after being assessed through teacher and students, the researchers concluded according to the needs of students with several indicators; (1) the purpose of developing a CLIL-based teaching material model encourages students to master the content of teaching materials and improve students Arabic speaking ability; (2) having a variety of topics consisting of courses in al-Qur'an, hadith, Fiqh and Islamic Tsaqafah; (3) the model of teaching material developed even though it focuses on the Arabic speaking ability as well as integrated with other language skills and linguistic aspects; (4) indicators of the success of the teaching material model developed can be seen from the results of teacher and students' perception; and (5) the role of lecturers in learning activities is limited to mediators and facilitators so as to provide freedom to students in developing knowledge, developing aspects of student language that are realized through speaking.

\section{References}

[1] D. Coyle, D., Hood, P. and Marsh, CLIL: Content and Language Integrated Learning. Cambridge: Cambridge University Press, 2010.

[2] M. T. Yaqub, "Developing Speaking Skill In Arabic Learners: A Proposal For Integration Of Product And Process Approaches," Eur. Sci. J., vol. vol.8, No., 2012.

[3] Z. \& Z. I. Arifin, "Arabic Speaking Skills as a PBJJ Course: Between Objectives and Reality," Procedia Soc. Behav. Sci. 18, vol. pp.534-536, 2011.

[4] et. a. Dourda, Kyriaki, "Content and Language Integrated Learning through an Online Game in Primary School: a Case Study,” Electron. J. E-Learning, vol. Vol. 12, no. Issue 3, 2014.

[5] Acep Hermawan, Metodologi Pembelajaran Bahasa Arab. Bandung. PT Remaja Rosdakarya Offset, 2009. 
[6] Abdurrahman bin Ibrahim al-Fauzan, Durus al-daurat al-tadribiyah li Mu'allimi al- Logah alArabiyah li Ghairi al-Naathiqin Biha. Masyru' al-Arabiyah li al-Jami.

[7] A. W. dan M. N. Rosyidi, Memahami Konsep Dasar Pembelajaran Arab. Malang: UIN Maliki Press, 2011.

[8] C. Dalton-Puffer, "Content-and-Language Integrated Learning: From Practice to Principles," Annu. Rev. Appl. Linguist., vol. Volume 31, p. p.182, 2011.

[9] Marsh et al, "European Framework for CLIL Teacher Education," Publ. by Eur. Cent. Mod. Lang., 2010.

[10] and U. S. Dalton-Puffer, Christine, Tarja Nikula, "Language Use and Language Learning in CLIL Classroom,” John Benjamins Publ. Co., p. p.105, 2010.

[11] Do Coyle, Philp Hood, \& David Marsh, "Content and Language Integrated Learning. Cambridge," Cambridge Univ. Press, vol. p.28, 2010.

[12] T. Brian, "Developing Materials For Language Teaching second edition,” p. p.2, 2013.

[13] J. C. Richards, Development in Language Teaching. United State of America: Cambridge University Press, 2001.

[14] dkk Hamid., Abdul, Pembelajaran Bahasa Arab (Pendekatan, Metode, Strategi, Materi, dan media). Malang: UIN Press, 2008.

[15] Tomlinson, "No Title," op.cit, p. h.98.

[16] R. R. Parse, "Qualitative Inquiry: The Path of Sciencing," NLNs, p. pp.57-58, 2001.

[17] R. Kiely, "Understanding CLIL as an Innovation," Studies in Second Language Learning and Teaching," vol. Vol 1, No, p. pp.154-157, 2011.

[18] K. A. Ghani, "Development of a Learning Module on Arabic Language Skills Outside of the Classroom," Procedia Soc. Behav. Sci. 18, pp. 154-162, 2011.

[19] E. a. Nurlaila, "Developing A Mahārah Al-Qirā'Ah Teaching Model Based On Grammatical And Discourse Competence,” Int. Ref. Res. J., vol. Vol.- VIII, no. Issue - 2(1), 2017. 